\title{
Interactions Between Microplastics and Heavy Metals in Aquatic Environments: A Review
}

\section{OPEN ACCESS}

Edited by:

Christopher Bagwell,

Pacific Northwest National Laboratory

(DOE), United States

Reviewed by:

Qiqing Chen,

East China Normal University, China

Yuyi Yang,

Chinese Academy of Sciences, China

Youji Wang,

Shanghai Ocean University, China

${ }^{*}$ Correspondence:

Xianhua Liu

Ixh@tju.edu.cn

Xiaochen Chen

chenxiaochen@fzu.edu.cn

Specialty section:

This article was submitted to

Microbiotechnology,

a section of the journal

Frontiers in Microbiology

Received: 12 January 2021

Accepted: 11 March 2021

Published: 22 April 2021

Citation:

Liu S, Shi J, Wang J, Dai Y, Li H,

Li J, Liu X, Chen X, Wang Z and Zhang $P$ (2021) Interactions Between Microplastics and Heavy Metals

in Aquatic Environments: A Review.

Front. Microbiol. 12:652520.

doi: 10.3389/fmicb.2021.652520

\author{
Sitong Liu', Jiafu Shi ${ }^{1}$, Jiao Wang ${ }^{1}$, Yexin Dai ${ }^{1}$, Hongyu Li', Jiayao Li', Xianhua Liu' ${ }^{1 *}$, \\ Xiaochen Chen ${ }^{2 *}$, Zhiyun Wang ${ }^{1}$ and Pingping Zhang ${ }^{3}$
}

'School of Environmental Science and Engineering, Tianjin University, Tianjin, China, ${ }^{2}$ Fujian Provincial Engineering Research Center of Rural Waste Recycling Technology, College of Environment and Resources, Fuzhou University, Fuzhou, China,

${ }^{3}$ College of Food Science and Engineering, Tianjin Agricultural University, Tianjin, China

Microplastics (MPs), tiny particles broken down from larger pieces of plastics, have accumulated everywhere on the earth. As an inert carbon stream in aquatic environment, they have been reported as carriers for heavy metals and exhibit diverse interactive effects. However, these interactions are still poorly understood, especially mechanisms driving these interactions and how they pose risks on living organisms. In this mini review, a bibliometric analysis in this field was conducted and then the mechanisms driving these interactions were examined, especially emphasizing the important roles of microorganisms on the interactions. Their combined toxic effects and the potential hazards to human health were also discussed. Finally, the future research directions in this field were suggested. This review summarized the recent research progress in this field and highlighted the essential roles of the microbes on the interactions between MPs and heavy metals with the hope to promote more studies to unveil action mechanisms and reduce/eliminate the risks associated with MP presence.

Keywords: microplastics, heavy metals, interactions, biofilm, microbe, aquatic environment

\section{INTRODUCTION}

Microplastics (MPs) have received global attention due to their ubiquitous presence in the environment and unknown hazards to organisms. Compared with the traditional plastic waste, the distinct character of MPs is their small size, which is precisely defined as plastic fragments and particles with a diameter of less than $5 \mathrm{~mm}$ (Thompson et al., 2004). There are two types of MPs: primary and secondary. Primary MPs may be intensively produced for various purposes, such as microbeads in commercial facial cleansers and resin particles (Bayo et al., 2017; So et al., 2018). Secondary MPs are decomposed from large pieces of plastic waste during environmental processes such as aging, weathering, and biodegradation (Gouin et al., 2011).

MPs can be accumulated in the environment due to their inert nature (Wang et al., 2021a). They have been proven to be widely distributed in our environment. For example, the abundance of MPs in the sediments of tropical Atlantic Ocean is 684.8 particles $/ \mathrm{m}^{2}$, and most of them are round particles and fragments with different shapes (Benson and Fred-Ahmadu, 2020). MPs have also been found in the sediments of China's three largest lakes (Zhang B. et al., 2020). Alarmingly, in Qinghai-Tibet Plateau, which has low plastic consumption and population density, high abundance of MPs was detected, which illustrates the wide distribution of MPs. In addition, as an emerging 
complex pollutant, MPs can produce various toxic effects on organisms. The exposure of aquatic organisms to MPs has been associated with short- and long-term adverse effects on organism's health, including biological feeding, reproduction, antioxidant defense and innate immunity (Murphy and Quinn, 2018; Wen et al., 2018a; Banaee et al., 2019; Oliviero et al., 2019).

Heavy metals are present in the environment from both naturally occurring and anthropogenic sources. As a contaminant that is widespread in the environment, heavy metals can enter water bodies continuously due to their non-degradable nature and are recycled and enriched in the aqueous environment. MPs and heavy metals are not only acting as persistent pollutants, their combined pollution poses a new threat to the world. Due to the large surface area, MPs can act like magnets for toxic pollutants and concentrate them to a very high level. Heavy metals had been found on the MPs from North Atlantic subtropical gyre (Prunier et al., 2019), São Paulo State in southeastern Brazil (Vedolin et al., 2018), beaches in southwest England (Massos and Turner, 2017), and western Europe (Turner et al., 2019).

Aquatic ecosystems contain a great diversity of microorganisms, which play critical roles in many biogeochemical processes. Their existence makes the interaction between MPs and heavy metals more complicated. Firstly, MPs can provide emergent ecological niche for microorganisms by formation of microbial biofilms, named plastisphere (Mincer et al., 2016; Yang et al., 2020). In the plastisphere, MPs can offer firm support for microbial colonization and even be served as carbon sources for microbial growth. Studies have shown that MP-associated biofilms could affect the physical and chemical properties of MPs and further affect the adsorption of chemical pollutants including heavy metals (Tu et al., 2020). Secondly, exposure to heavy metals can impact biofilm formation and bring structural changes to the biofilm matrix, which further impact the adsorption behavior of heavy metals (de Araújo and de Oliveira, 2020). Although the role played by biofilms has become a hot spot in the MP studies, their influence on the fate of MPs and heavy metals is still not well understood.

As a whole, a great deal of work has been done to analyze the type, size, shape, color, and abundance of MPs in order to explain the source, sink, and destination of MPs in the environment. In the meantime, many types of heavy metals have also been detected on the surface of MPs, which showed that MPs can be unneglectable carriers of heavy metals. As a crucial biotic components in aquatic systems, microbes may also play a key role in modulating the interaction between MPs and heavy metals. Until now, there is still lack of comprehensive review papers on the interactions between MPs and heavy metals. This review aims to fill in this gap and highlight key future research areas in this field. The microbe's important roles on the interactions will also be emphasized. The following aspects will be focused on (1) conducting a bibliometric analysis in this field to summarize the recent research progress and trend, (2) examining the interaction behaviors and underlying mechanisms between MPs and heavy metals, (3) discussing the combined toxic effects and the potential hazards to human health, and (4) suggesting the future research directions in this field. This review will help to deepen the understanding of the sources, transport routes, and ecological risks of MPs and heavy metals, and promote the actions to reduce their possible risks on the ecological system and human health.

\section{BIBLIOMETRIC ANALYSIS}

In order to better understand the current state of research in the field of MPs and heavy metals, a bibliometric analysis was conducted. The original literature data were collected from the Web of Science with the search strategy of "microplastic* and ('heavy metal*' or copper or lead or zinc or iron or cobalt or nickel or manganese or cadmium or mercury)," and a total of 978 papers published between 2006 and 2021 were identified. The software CiteSpace 5.7.R3 was used to conduct burst keywords analysis and co-occurrence keyword network analysis, and Gephi 0.9.2 was employed to visualize the keywords network.

Burst keywords can reflect emerging trends and hot spots. Figure 1 shows the burst keywords detection result between 2006 and 2021. Among all the burst keywords, the keyword nanoparticle has the strongest burst intensity (7.28), which is much higher than other keywords, indicating that research related to MPs is no longer limited to the micron level, but has a tendency to move to the nanometer level, which is also confirmed by the keyword nanoplastics becoming an emerging buzzword in 2019-2021. As one of the most popular heavy metals related to MP study, copper has the second burst intensity (5.8). Among all the popular keywords, the keyword film has the longest duration of hotness, receiving strong attention for 10 consecutive years from 2009 to 2018 , which indicates that there is still a large amount of research focusing on basic research in the field of MPs. The rise of the keyword cytotoxicity means that the research on the toxic effects of MPs and heavy metals at the cellular level is being further developed. Keywords with frequencies over five times were analyzed by co-occurrence mapping analysis (Figure 2). MPs, heavy metals, and adsorption were the top three keywords with the highest frequency and degree and were closely linked to other nodes. At the same time, in order to better understand the role of microbes in this field, keyword co-occurrence mapping analysis on MPs, heavy metals, and microbes was also conducted (Figure 3). Among the top keywords, biofilm has a high betweenness centrality and degree, demonstrating that it plays an important role in the interaction network between heavy metals and MPs. However, there are not many literature reports on topic, and only 94 papers were retrieved, implying that this field still has a great potential for further development.

\section{INTERACTION CHARACTERISTICS AND DRIVING MECHANISMS}

\section{Influence of Environmental Factors on Interactions Between MPs and Heavy Metals}

Table 1 lists impacts of different environmental factors on the interactions between MPs and heavy metals. These factors 


\section{Top 20 Keywords with the Strongest Citation Bursts}

\begin{tabular}{|c|c|c|c|c|c|}
\hline Keywords & Year & Strength & Begin & End & $2006-2021$ \\
\hline copper & 2006 & 5.8 & 2006 & 2013 & 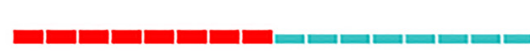 \\
\hline alloy & 2006 & 5.17 & 2006 & 2010 & تصعص=سשص \\
\hline surface & 2006 & 3.68 & 2007 & 2008 & $-\pi$ \\
\hline film & 2006 & 5.04 & 2009 & 2018 & 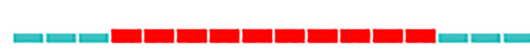 \\
\hline design & 2006 & 3.11 & 2009 & 2011 & 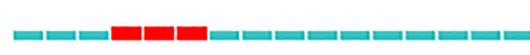 \\
\hline aqueous solution & 2006 & 3.04 & 2009 & 2014 & سשصسصس \\
\hline thin film & 2006 & 5.2 & 2010 & 2014 & 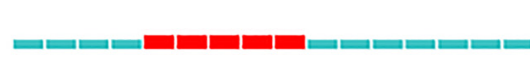 \\
\hline mechanical property & 2006 & 3.58 & 2011 & 2017 & 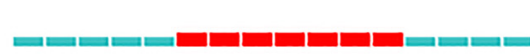 \\
\hline nanoparticle & 2006 & 7.28 & 2012 & 2016 & ב \\
\hline parameter & 2006 & 4.85 & 2012 & 2014 & 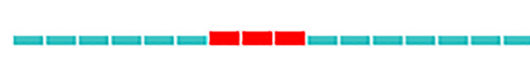 \\
\hline microstructure & 2006 & 3.17 & 2013 & 2018 & = בص \\
\hline fabrication & 2006 & 5.55 & 2014 & 2016 & 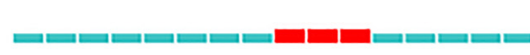 \\
\hline series resistance & 2006 & 5.22 & 2014 & 2016 & 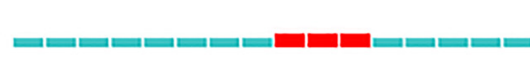 \\
\hline microsphere & 2006 & 3.73 & 2014 & 2015 & 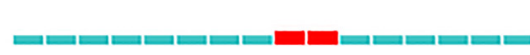 \\
\hline reduction & 2006 & 3.06 & 2014 & 2017 & שصשصחשי \\
\hline marine environment & 2006 & 4.88 & 2015 & 2018 & : \\
\hline mercury & 2006 & 3.23 & 2017 & 2018 & =्ח \\
\hline cytotoxicity & 2006 & 3.23 & 2017 & 2018 & 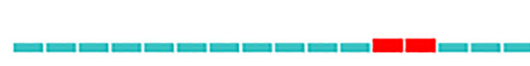 \\
\hline sea & 2006 & 3.14 & 2018 & 2019 & 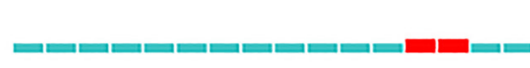 \\
\hline nanoplastics & 2006 & 3.06 & 2019 & 2021 & \\
\hline
\end{tabular}

FIGURE 1 | Top 20 keywords with the strongest citation bursts during 2006-2021.

include aging, temperature, $\mathrm{pH}$, contact time, ionic strength, and particle size. Aging, whether with UV irradiation or with aging agents such as $\mathrm{H}_{2} \mathrm{O}_{2}$ and Fenton, can increase the adsorption capacity of MPs for heavy metals (Wang et al., 2019a). This observation was consistent across different studies (Mao et al., 2020; Lang et al., 2020; Wang Q. et al., 2020). The mechanism for enhanced adsorption may be due to the increase of specific surface area and oxygen-containing functional groups after aging. Compared with the unaged PET, new ketone groups were found on the surface of the PET aged by UV (Wang Q. et al., 2020). Photodegradation can also break the bonds on the MP surface and form new carboxyl groups (Bandow et al., 2017; Liu et al., 2019). These oxygen-containing groups can increase the polarity of MPs (Holmes et al., 2012) and make the MP surface more reactive (Holmes et al., 2014), leading to an increase of the adsorption capacity for metal ions. In terms of $\mathrm{pH}$, generally only the case of $\mathrm{pH}<7$ will be considered because metal ions will precipitate under alkaline conditions. The $\mathrm{pH}$ can significantly affect the adsorption capacity of MPs to heavy metals. When $\mathrm{pH}$ is less than a certain value, MPs will not interact with heavy metals (Tang et al., 2020). Generally, increased pH level results in increased adsorption capacity for heavy metals (Guo et al., 2020); however, there are also different opinions (Zhang W. et al., 2020). The different observations may be due to the use of different heavy metals in these studies. Metal ions in the former case were usually positively charged, such as $\mathrm{Cd}^{2+}$, while in the latter case, they were normally negatively charged, such as $\mathrm{CrO}_{4}{ }^{2-}$. Taking the latter as an example, when the $\mathrm{pH}$ is less than 3 , the surface of the MPs (PE) is positively charged, and the zeta potential and electrostatic repulsion are low. The negatively charged $\mathrm{CrO}_{4}{ }^{2-}$ are more likely to be strongly attracted by the positively charged MPs. However, with the increase of $\mathrm{pH}$, the surface of the MPs 


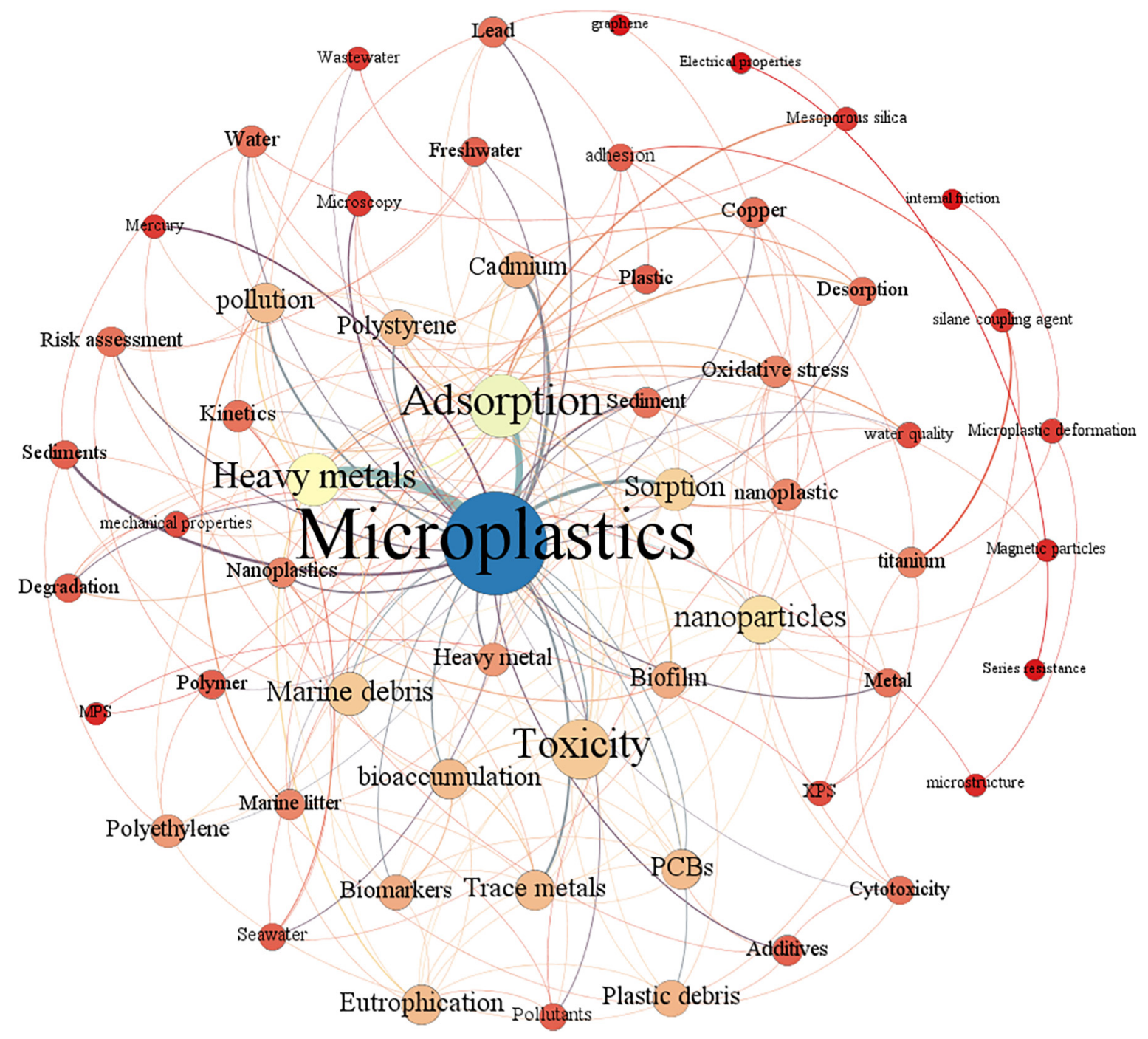

FIGURE 2 | Co-occurrence analysis of keywords with a word frequency of more than five times. The data come from a literature search with MPs and heavy metals as the subject terms. Each node is represented as a keyword, edges represent the link between keywords, the color of the node is rendered in degrees, and the color of the edge is rendered in the weight of the edge.

(PE) becomes negatively charged and the adsorption capacity for $\mathrm{CrO}_{4}{ }^{2-}$ decreases. As for the temperature, the general opinion is that high temperature will benefit the adsorption of heavy metals on MPs (Oz et al., 2019; Wang T. et al., 2020). The possible explanation for this observation is that the adsorption process is an endothermic reaction; thus, the spontaneity of the adsorption process may increase with the increase of temperature.

\section{Adsorption Kinetics and Isotherms of Heavy Metals on MPs}

The kinetic study of the adsorption process can describe the rate of heavy metal adsorption by MPs, and the fitting of the kinetic model allows further analysis of the adsorption mechanism. Commonly used adsorption models include pseudofirst-order kinetic model, pseudo-second-order kinetic model,
Elovich kinetic model, Boyd model, Weber-Morris Model, and Bangham channel diffusion model. The adsorption process was usually fitted with a pseudo first-order kinetic model (Zhang et al., 2018; Zon et al., 2018); however, some researchers also reported that the pseudo-second-level kinetic model can yield a better fit (Nethaji et al., 2013; Taha et al., 2016; Oz et al., 2019; Guo et al., 2020; Tang et al., 2020). This model assumes that the adsorption of heavy metals by MPs is mainly controlled by the chemisorption mechanism, involving the sharing or transfer of electron pairs, and is not controlled by the material transport step. The Weber-Morris model was used to describe the multistage nature of the adsorption process (Nethaji et al., 2013; Taha et al., 2016; Zon et al., 2018; Oz et al., 2019). In this model, adsorption may occur in multiple steps. Guo et al. $(2015,2020)$ divided the adsorption process into three steps. The first step is the rapid combination of heavy metal ions with active sites on MP surface, 


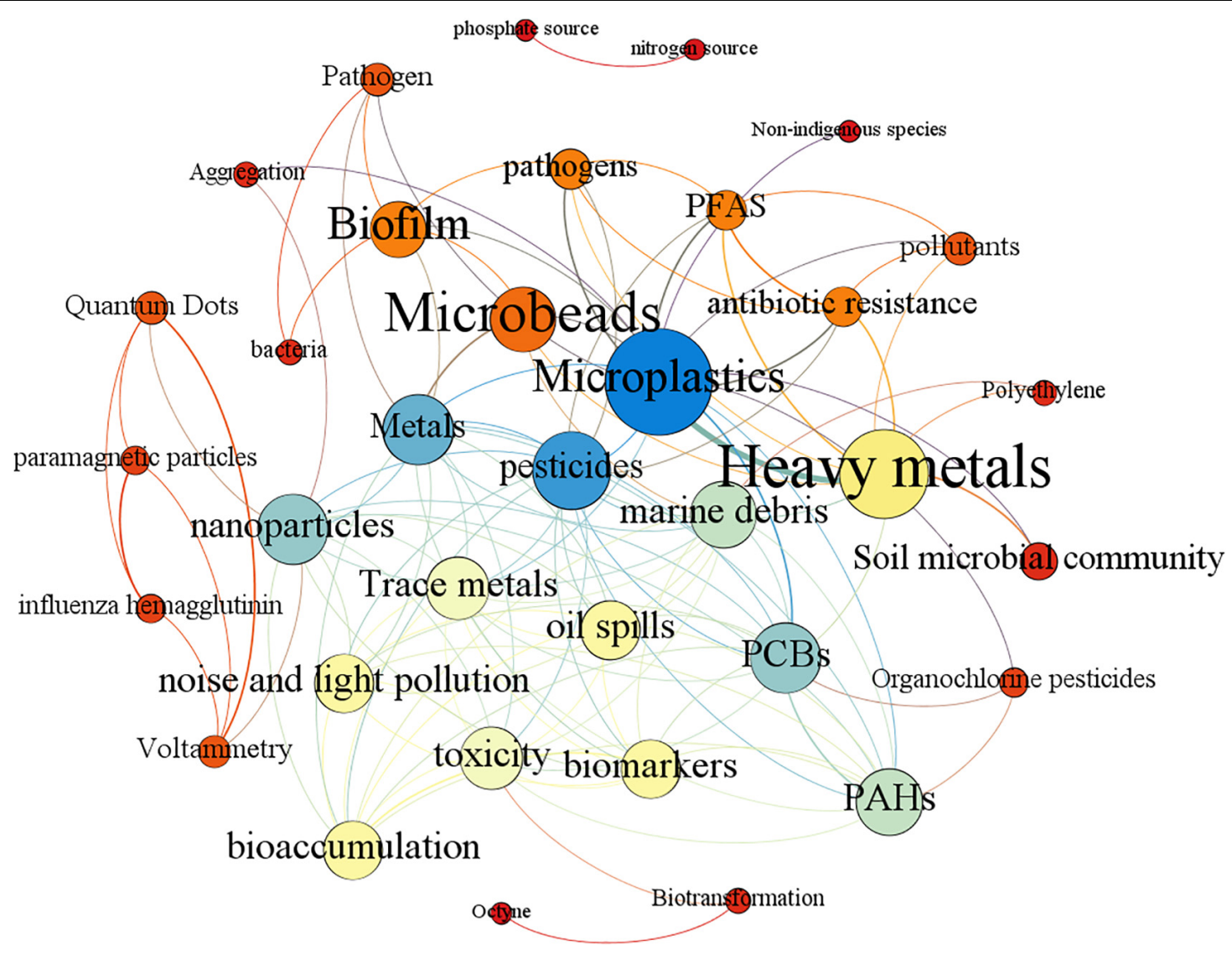

FIGURE 3 | Co-occurrence analysis of keywords with a word frequency of more than five times. The data come from a literature search with MPs, heavy metals, and microbes as the subject terms. Each node is represented as a keyword, edges represent the link between keywords, the color of the node is rendered in degrees, and the color of the edge is rendered in the weight of the edge.

which is mainly attributed to the covalent and van der Waals forces. When this binding process reaches a saturation, due to the increased diffusion resistance, the adsorption enters the second step, and the heavy metal begins to diffuse slowly into the pores of the MP particles. In the final step, the adsorption rate decreases significantly, eventually reaching an equilibrium state between adsorption and desorption.

The adsorption isotherm can be used to describe the distribution of pollutants between the solid and liquid phases in the adsorption equilibrium state, and the most commonly used models are the Langmuir isotherm model (Langmuir, 1918) and the Freundlich isotherm model. The Langmuir isotherm model assumes that there is no interaction force between the adsorbed molecules and only monolayer adsorption can be formed on the MP surface, while the Freundlich isotherm model is an empirical equation with no assumptions. Some researchers reported that the adsorption process of MPs for heavy metals can be described by the Langmuir isotherm model (Tang et al., 2020; Wang T. et al., 2020; Zhang S. et al., 2020), while some others declared that the Freundlich isotherm model was better (Fang et al., 2019; Purwiyanto et al., 2020; Shan et al., 2020). In the Freundlich isotherm model, the adsorption process is a multilayer adsorption that occurs on a heterogeneous surface, and pollutant molecules will first occupy high-energy adsorption sites and then diffuse to low-energy adsorption sites (Abdurahman et al., 2020; Wang T. et al., 2020). There are also studies showing that both Langmuir and Freundlich models can successfully describe adsorption isotherms (Zon et al., 2018; Dong et al., 2020).

In general, the adsorption mechanism between MPs and heavy metals can be generally described by electrostatic interactions, van der Waals forces, and $\pi-\pi$ interactions (Fu et al., 2020; Lin et al., 2021; Torres et al., 2021). It was shown that all MPs have a $\mathrm{pH}$ point of zero charge ( $\mathrm{pHpzc}$ ) around 3, which implies that in the natural aqueous environment, MPs should carry a negative charge on their surface (Lin et al., 2021). The electrostatic attraction between these negatively charged MPs and positively charged metal ions promotes the adsorption behavior. Compared to electrostatic interactions, van der Waals forces and $\pi-\pi$ interactions play a relatively small role. However, they can further promote the sorption capacity (Torres et al., 2021). Their occurrence depends on the polymer type; e.g., PE (aliphatic polymer) exhibits van der Waals interactions, while PS (aromatic polymer) exhibits mainly $\pi-\pi$ interactions. Different polymers have different polarity, crystallinity, and surface functional groups, resulting in different adsorption behavior during adsorption (Kim et al., 2017; Chen et al., 2019; 
TABLE 1 | Research on the characteristics of interaction between MPs and heavy metals.

\begin{tabular}{|c|c|c|c|c|}
\hline Types of MPs & Types of heavy metals & Factors & Results & References \\
\hline \multirow[t]{3}{*}{ PE PP PS PVC } & $\mathrm{Cd}^{2+}$ & $\mathrm{pH}$ & $\begin{array}{l}\text { The sorption tendency increased as the } \mathrm{pH} \text { increased, } \\
\mathrm{PVC}>\mathrm{PS}>\mathrm{PP}>\mathrm{PE}\end{array}$ & Guo et al., 2020 \\
\hline & & lonic strength & $\begin{array}{l}\text { The sorption capacity decreased as the salinity increased, } \\
\text { PVC }>\text { PS }>\text { PP }>\text { PE }\end{array}$ & \\
\hline & & Humic acid $(\mathrm{HA})$ & $\begin{array}{l}\text { The sorption tendency increased as the HA increased, } \\
\text { PVC }>\text { PS }>\text { PP }>\text { PE }\end{array}$ & \\
\hline PA & $\mathrm{Pb}^{2+}$ & $\mathrm{pH}$ & $\begin{array}{l}\text { The minimum adsorption efficiency (\%) was } 3.37 \% \text { at } \mathrm{pH} 2.5 \text {, the maximum } \\
\text { adsorption efficiency (\%) of } 91.24 \% \text { was acquired at } \mathrm{pH} 6 \text {. }\end{array}$ & Tang et al., 2020 \\
\hline \multirow[t]{3}{*}{ PE } & $\mathrm{Cr}^{3+}$ & $\mathrm{pH}$ & $\begin{array}{l}\text { The adsorption capability was increased when the dosage of PE MPs was } \\
\text { increased }\end{array}$ & Zhang W. et al., 2020 \\
\hline & & SDBS & $\begin{array}{l}\text { The addition of SDBS can improve the adsorption capacity of } \mathrm{PE} \text { on } \mathrm{Cr}^{3+} \text {. } \\
\text { The peak of the adsorption capacity was at SDBS concentration between } 1 \\
\text { and } 1.5 \mathrm{mM}\end{array}$ & \\
\hline & & SDBS and $\mathrm{pH}$ & $\begin{array}{l}\mathrm{pH}<6 \text {, with the increase of SDBS, the adsorption efficiency increases. } \\
\mathrm{pH}>6, \mathrm{SDBS} \text { would compete with } \mathrm{CrO}_{4}{ }^{2+} \text { for occupying the adsorption } \\
\text { sites of PE microplastic. }\end{array}$ & \\
\hline \multirow[t]{2}{*}{ PET PA EVA } & $\mathrm{Pb}^{2+}$ & $\mathrm{pH}$ & $\begin{array}{l}\mathrm{pH} \text { is the most significant factor, the maximum adsorption was acquired at } \\
\mathrm{pH} 5.5 \text {. }\end{array}$ & Oz et al., 2019 \\
\hline & & Temperature & $\begin{array}{l}\text { Adsorption capacity increases for PET, PA, and EVA with increasing } \\
\text { temperatures but it was not affected much. }\end{array}$ & \\
\hline PE & $\mathrm{Cr}$ & Concentration of chromium & $\begin{array}{l}\text { The higher the initial concentration of chromium, the higher the adsorption } \\
\text { capacity }\end{array}$ & Zon et al., 2018 \\
\hline \multirow[t]{5}{*}{ PET } & $\mathrm{Zn}^{2+} \mathrm{Cu}^{2+}$ & Aging & $\begin{array}{l}\text { There is a positive correlation between the degree of aging and the } \\
\text { adsorption capacity }\end{array}$ & Wang Q. et al., 2020 \\
\hline & & Microplastic dosage & $\begin{array}{l}\text { The more MP doses, the higher sorption capacity of metal ions was fully } \\
\text { realized }\end{array}$ & \\
\hline & & Time & The longer the adsorption time, the greater the adsorption capacity. & \\
\hline & & $\mathrm{pH}$ & The $\mathrm{pH}$ range is $3-7$; the higher the $\mathrm{pH}$, the greater the adsorption capacity. & \\
\hline & & Temperature & $\begin{array}{l}\text { The temperature range is } 288 \mathrm{~K}-318 \mathrm{~K} \text {; the higher the temperature, the } \\
\text { greater the adsorption capacity. }\end{array}$ & \\
\hline
\end{tabular}

PA, Polyamide; PE, Polyethylene; PET, Polyethylene Terephthalate; PP, Polypropylene; PS, Polystyrene; PVC, Polyvinyl Chloride; EVA, Ethylene Vinyl Acetate Copolymer; SDBS, Sodium Dodecyl Benzene Sulfonate.

Loncarski et al., 2020). Guo et al. (2020) studied the adsorption of cadmium ions by four types of MPs (PP, PE, PS, and PVC) and found that the order of adsorption capacity was PVC $>$ PS $>$ PP $>$ PE. Llorca et al. (2020) also reported that PET and PS had higher affinity for pollutants than PE. As simple non-polar crystalline polymers, $\mathrm{PE}$ and $\mathrm{PP}$ have no functional groups and can only adsorb contaminants in a single layer with van der Waals forces, so the adsorption capacity is relatively small (Chen et al., 2019). For PS and PET, the polarity is increased due to the presence of phenyl and ester groups, and the adsorption capacity can be increased through the interaction of $\pi-\pi$ bonds with pollutants (Llorca et al., 2020; Loncarski et al., 2020). PVC, because it contains polar atomic chlorine, is a strong polar polymer, so it has very large adsorption capacity (Brennecke et al., 2016).

\section{Role of Microbes on the Interactions Between MPs and Heavy Metals}

The aquatic environment is a highly complex ecosystem, and there are dynamic interactions between biotic and abiotic components (de Araújo and de Oliveira, 2020). In addition to physical and chemical environmental factors, biological factors can affect the adsorption of heavy metals by MPs. The influence of microbial biofilm is one of the most concerned biological factors and it plays an important role in determining the MP surface properties. Tu et al. (2020) found that biofilm formation reduced the hydrophobicity of the PE MP surface and increased the abundance of carboxyl and ketone groups on the MP surface, which then increased the adsorption capacity for metal ions. Some studies revealed that the growth of biofilms can positively affect the adsorption of heavy metals and concentration of heavy metals on MPs will increase as the biofilm matures (Richard et al., 2019; Qi et al., 2021). It must be noted, however, that the long-term dynamic change of heavy metal loads on MPs during the whole biofilm development remains largely unknown. Sinking of floating MPs caused by biofilm development further complicates the problem (Rummel et al., 2017). Much more work need to be done to quantitatively determine the influence of biofilm on heavy metal adsorption for a better understanding of their interactions in the aquatic environment. In addition, Jin et al. (2020) reported how biofilm on MPs affects the uptake and fate of hydrophobic organic compounds. They found that the high temperature in the summer was more favorable for the colonization of highly active bacteria on the MP surface, and interactions between pollutants and attached microorganisms in the biofilm essentially depend on pollutant features and microbial activity. 
In the meantime, environmental factors may indirectly exert influence on MPs by changing biofilm structures on the MP surface. Wang L. et al. (2020) found that nutrient salts, total nitrogen, total phosphorus, and $\mathrm{pH}$ have a greater influence on colony structure, while MP physical and chemical properties such as particle size and contact angle have less influence. Other reports (Di Pippo et al., 2020; Feng et al., 2020; Li et al., 2020) also confirmed that bacterial composition varies significantly based on marine habitat and exposure time, rather than polymer type. In the presence of heavy metals, microbial cells in biofilms can produce more extracellular polymeric substances (EPS) to protect themselves from the harsh environment (Sheng et al., 2010). EPS have been confirmed to play a very important role in biosorption of heavy metals. The biomacromolecules in EPS contain large amount of ionizable functional groups, such as hydroxyl, phosphoric, carboxyl, and amine groups, which enable EPS to absorb heavy metals. Figure 4 shows the proposed mechanisms of biofilm involved in the interactions between MPs and heavy metals. EPS can also inhibit diffusion of heavy metals in the matrix and decreases the concentration of heavy metals to sublethal concentrations. The survival of exposed microbes thus develops the ability of tolerance or resistance to heavy metals (Flemming et al., 2016). How these selection processes influence the fate of MPs and heavy metals is still unknown, and there is an urgent need to better understand these interactions (Kirstein et al., 2016; Rummel et al., 2017).

\section{COMBINED TOXIC EFFECTS AND THE POTENTIAL HAZARDS TO HUMAN HEALTH}

Contamination of aquatic systems with MPs and heavy metals is a global environmental problem of public health concern.
Both MPs and heavy metals can accumulate at high level in the environment and consequently contaminate the food chains (Figure 5). The pollution of heavy metals to the environment has long been recognized (Svecevièius et al., 2014), but MPs were once regarded as relatively inert pollutants (Ashton et al., 2010). However, many studies have shown that MPs can adsorb and release heavy metals, and their combined exposure may pose a potential threat to ecological system and human being (Akhbarizadeh et al., 2017).

\section{Toxic Effects on Aquatic Organisms}

Aquatic organisms can ingest MPs through direct ingestion, filtering ingestion, and food chain transfer, which can produce certain toxic effects when they accumulate at high levels in the body. Murphy and Quinn (2018) reported that MPs can reduce the feeding rate of freshwater snakes and cause them to produce non-lethal morphological changes, but they have no significant effect on their reproduction. Wen et al. (2018b) found that MPs can reduce the activity of acetylcholinesterase, thereby affecting neuromuscular and reducing its feeding rate. The adverse effects were more obvious when aquatic organisms were exposed to both MPs and heavy metals. Banaee et al. (2019) reported that when Cd and MPs were applied to carp, the blood biochemical and immunological indicators of carp changed significantly. The acetylcholinesterase activity in plasma and the total protein content were both reduced, and the triglycerides and cholesterol levels were elevated; thus, the immune system level was reduced, making it more susceptible to infection and death. Wen et al. (2018a) also reached the same conclusion. They found that when Cd and MPs were co-applied to Amazon discus fish, severe oxidative stress response and innate immune defense were generated compared to the administration of a single poison. However, Sun et al. (2019) showed that the combination of MPs and heavy metals can induce hippocampal oxidative damage and

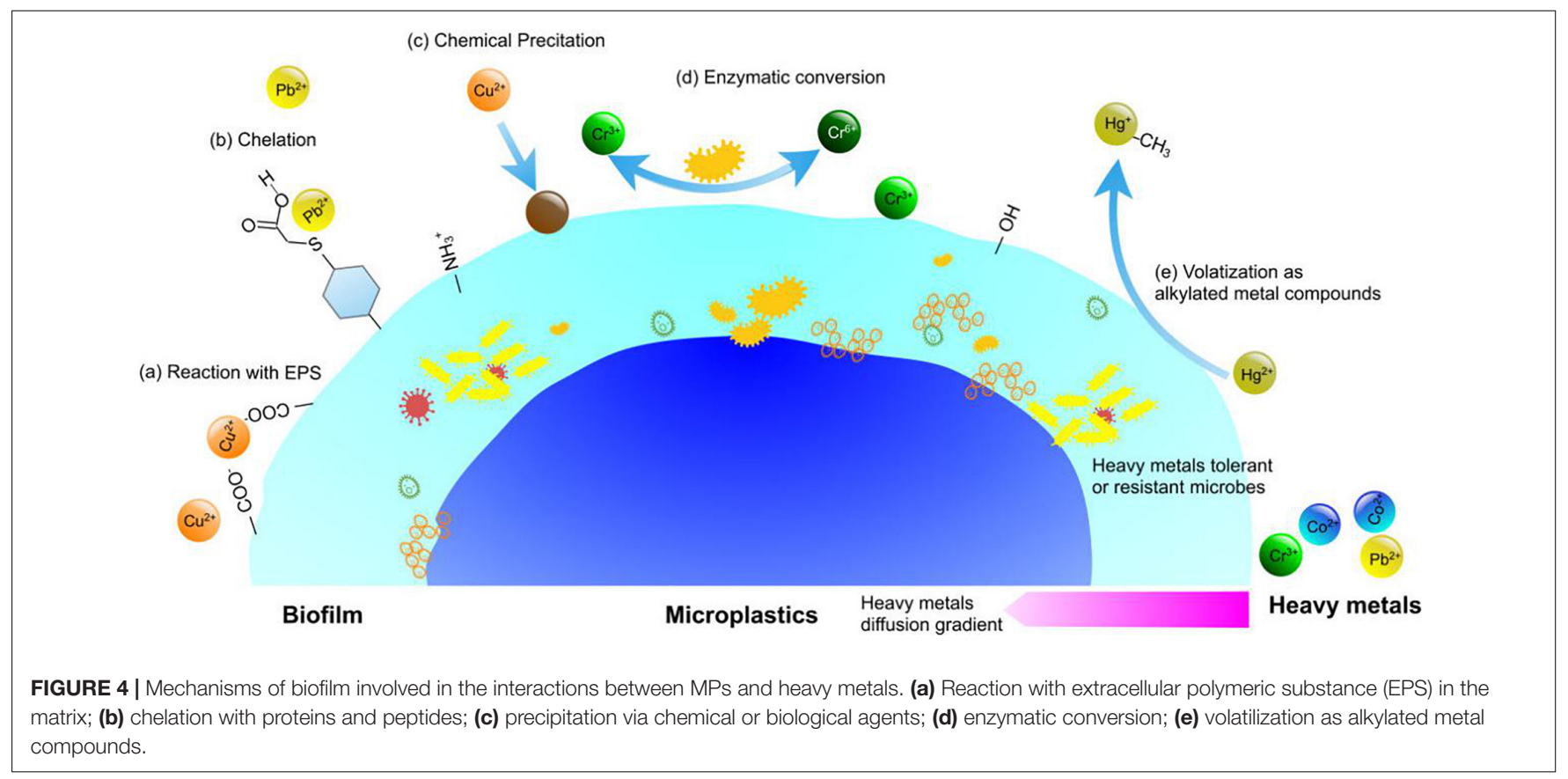




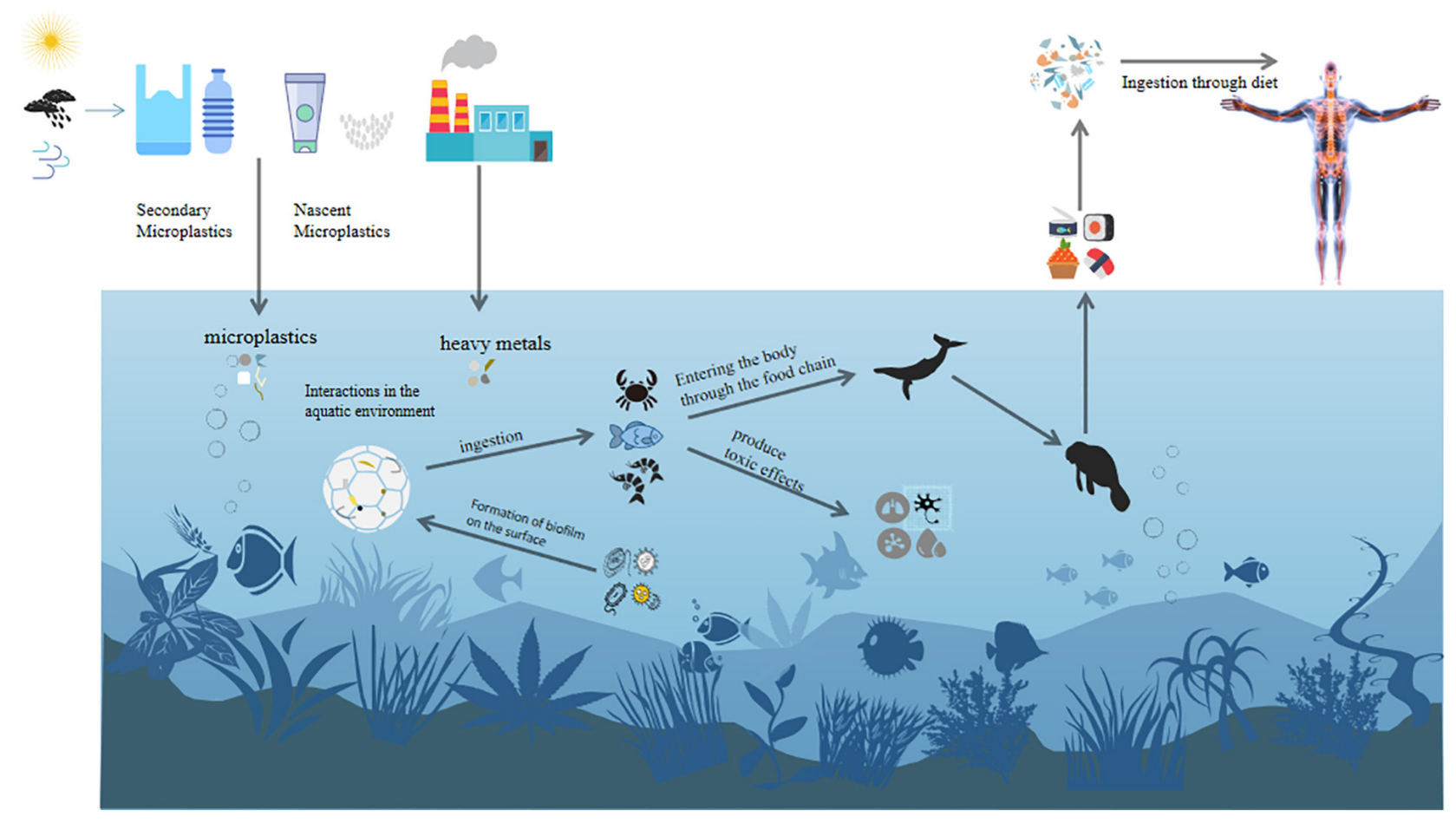

FIGURE 5 | Ecological risks of MPs and heavy metals.

increase mortality, but this effect was mainly caused by heavy metals, not MPs. Yan et al. (2020) also pointed out that the adverse impacts of MPs and heavy metals on the development of marine medaka gonads was mainly due to heavy metals. Actually, those differences are understandable. With the different types of MPs and heavy metals, as well as test species, toxic effects are expected to be different. For example, cellophane is easy to accumulate in the gills, mantle, and muscles of oysters, so it has a greater impact on food intake and oxygen uptake, while polyester is more likely to accumulate in the digestive glands and has a greater impact on the absorption of protein, cholesterol, and fat (Zhu et al., 2020). As far as heavy metals are concerned, $\mathrm{Pb}$ can affect the nervous system by directly damaging brain cells, while Cd can selectively deposit in the kidneys and liver and cause kidney disease (Tchounwou et al., 2012). Heavy metals in different valence states show different toxicity; for example, hexavalent chromium is known to be more toxic than trivalent chromium. Furthermore, larger organisms such as sea turtles and fish are usually more resistant to MPs than microorganisms and therefore have a lower lethality rate (van Franeker et al., 2011; Kleinteich et al., 2018; Duncan et al., 2019; Oliviero et al., 2019; Wang et al., 2019b).

\section{Potential Hazards to Human Health}

Both the World Health Organization [World Health Organization (Who), 2019] and Science Advice for Policy by European Academies (Sapea Working Group on Microplastics, 2019) stated that it is currently impossible to fully determine whether the risk of ingesting MPs exists due to the lack of human toxicity data on exposure to MPs. However, the inability to determine whether the risk exists does not mean that the risk is negligible. Therefore, many researchers have tried to use different test methods or models to assess the potential human health risks of MPs.

Food chain threat is the first thing to be considered. Robin et al. (2020) reported that polyethylene MPs were found in 15 of the 70 commercial fishes collected in Indian waters. Steer et al. (2017) also found $2.9 \%$ of the fry collected in the English Channel ingested blue fiber-based MPs. Fish were also reported to accumulate high levels of heavy metals. Tayebi and Sobhanardakani (2019) found that average levels of $\mathrm{Cd}$ and $\mathrm{Pb}$ in imported tilapia were found to be higher than the World Health Organization (WHO) maximum permissible levels (MPLs). Milatou et al. (2020) also found that total mercury levels in Mediterranean Atlantic bluefin tuna exceeded the maximum levels set by the European Commission. The presence of MPs in fish is supposed to increase their uptake of heavy metals, which will inevitably increase the health risk to humans through the food chain. There are many studies that demonstrated the wide presence of MPs and/or heavy metals in fish body (Akhbarizadeh et al., 2018; Milatou et al., 2020; Ta and Babel, 2020; Zitouni et al., 2020; Abidli et al., 2021; Covernton et al., 2021; Jonathan et al., 2021; Martinez-Tavera et al., 2021; Sarkar et al., 2021). For example, Akhbarizadeh et al. (2018) investigated MPs and metals' concentration in muscles of both benthic and pelagic fish species from northeast of Persian Gulf and assess the risk of their consumption; Sarkar et al. (2021) detected MPs (PET and PE) and high levels of heavy metals (AS, Cd, $\mathrm{Cr}, \mathrm{Cu}, \mathrm{Ni}$, 
$\mathrm{Pb}$, and $\mathrm{Zn}$ ) in both pond water and fish meat. Beside fish, MPs in other animals were also found carrying toxic metals, and positive relationships between MP ingestion and toxic metal concentration were reported (English et al., 2015; Akhbarizadeh et al., 2018). However, the reason for MP increase in heavy metals in animals is still not clear. It is reasonable to doubt the vector roles that MPs play compared to natural particles because of their relatively low abundance. In natural aquatic environments, there are many natural particulate matter that can bind heavy metals to varying degrees, including sands, clay, metal oxides and hydroxides, humus, microbes, and other small-size substances. If surface adsorption is the main sorption mechanism, the influence of other natural media should be similar or equal to that of MPs, unless heavy metal levels are higher in most plastics or animals have a preference for ingesting MPs. More investigation are needed to fully understand the mechanism of heavy metal accumulation by MPs, and how MPs compete natural particulate matter as heavy metal vectors.

A recent study found that MPs can be detected in human excreta, which confirms that MPs can indeed enter the human body through various pathways (Schwabl et al., 2019). As an effective carrier of heavy metals, MPs can form complex contaminants with heavy metals, which may affect the immune system and induce various diseases when they enter the body. The effects of heavy metals on human health have been widely reported (Zahra, 2017; Fu and Xi, 2019). For example, Hg can cause chronic neurotoxicity in humans; $\mathrm{Pb}$ invasion can damage the nervous system and digestive system, making people appear anemic, with low immunity, abdominal pain, and other symptoms; $\mathrm{Cr}$ is easy to enter human cells, causing DNA damage, and is carcinogenic and may induce genetic mutations. To more directly assess the risk to human health from the combined contamination of heavy metals and MPs, Godoy et al. (2020) used a dynamic gastrointestinal simulation device to study the bioaccessibility of $\mathrm{Cr}$ and $\mathrm{Pb}$ in MPs in the human body and found that the release rate and content of these two heavy metals were different. Cr was mainly released in the stomach, while $\mathrm{Pb}$ was released more in the duodenum. Liao and Yang (2020) conducted in vitro experiments on the whole digestive system for $\mathrm{Cr}$-containing MPs and found that $\mathrm{Cr}$ is mainly released into the body during gastric digestion, and $\mathrm{Cr}$ has a higher bioavailability in degradable MPs [such as polylactic acid (PLA)] compared to non-degradable MPs (PE, PP, PVC, and PS). As an emerging persistent pollutant, MPs can be harmful to animals and human beings. The common response to MP exposure includes oxidative stress, inflammation, metabolism disruption, cytotoxicity, and translocation to other tissues (Rahman et al., 2021; Wang et al., 2021b). Due to the persistent nature of MPs, the living organisms might also get long-term exposure to ingested MPs, which can lead to chronic responses, such as necrosis, compromised immune function, and reproductive and developmental damage (Smith et al., 2018; Yin et al., 2021). The effects of chronic exposure to MPs appear to be very variable, depending on the exposure level and individual susceptibility. Furthermore, the MPs in real life are a cocktail of different MPs, non-polymers, additives, heavy metals, and pathogenic microbes. Its combined exposure is tremendously different from those of individual components, which further complicate the problem (Hirt and Body-Malapel, 2020; Rahman et al., 2021). Obviously, the risk assessment of MPs and heavy metals on human health is complex, and it is still impossible to state with certainty the extent to which the combined pollution of MPs and heavy metals is harmful to human health. Regional differences, pollution status, physiological characteristics of organisms, and dietary habits can affect the risk assessment results, so it is important to fully consider regional characteristics and applicability of the results when conducting risk assessment, which may facilitate scientific regulation. Although the risk is not clear, it is believed that the combined exposure of MPs and heavy metals can increase the adverse effects and bring unpredictable harm to biosphere. Researchers are recommended to address the knowledge gaps in understanding the toxicity of combined cumulative exposure of MPs and heavy metals and develop standardized methods for evaluating their potential risks.

\section{Role of Microorganisms on the Toxic Effects of MPs and Heavy Metals}

MPs provide habitat for microbial communities and to some extent alter their lifestyle, metabolic pathways, and biogeochemical activities (Bryant et al., 2016). It has been shown that biofilms associated with MPs have the ability to alter nitrogen and phosphorus cycling processes in aquatic systems, and this effect is thought to be achieved through increased denitrification capacity and microbe-mediated phosphorus (P) conversion (Chen et al., 2020). Xue et al. (2020) also reported the impact of bacterial communities in plastisphere on the biogeochemical cycle, and they found that the microbes related to nitrification, denitrification, and sulfur cycles on plastic fragments have higher levels than the surrounding water. It implied that nitrogen- and sulfur-related metabolism was more vigorous in the biofilm. In addition, microorganisms can use MPs or their degradation intermediates as carbon sources (Rogers et al., 2020). Intermediate degradation products of MPs from abiotic processes, such as dissolved organic carbon (DOC) as well as methane and other hydrocarbon gasses, can also be used as potential electron donors for microbes, thus affecting the carbon cycle in aquatic systems. MPs can also play a role in the transport of trace metals. Guan et al. (2020) reported that the development of biofilms enhanced the role of MPs in the transport and fate of trace metals [Ni(II), $\mathrm{Cu}(\mathrm{II}), \mathrm{Zn}(\mathrm{II})$, and $\mathrm{Cd}(\mathrm{II})]$ in the aqueous environment. They found that biofilms altered the kinetics of trace metal adsorption on MPs, mainly as a result of the complexation of functional groups on the surfaces of both MPs and biofilms.

Pathogenic bacteria can travel the waters on MPs. Feng et al. (2020) found that MP surfaces are enriched with Vibrio, Erythrobacteriaceae, and Xanthobacteriaceae, which can cause coral bleaching and tissue damage. Sun et al. (2020) also reported that the potentially pathogenic Vibrio on MP surfaces can increase the ecological risk of MPs to the marine aquaculture industry. Many studies have found that the bacterial communities that accumulated on the surface of MPs were more correlated with human disease than in the water column (Wang J. et al., 
2020; Xue et al., 2020). Laverty et al. (2020) isolated three human pathogens from MPs, including Vibrio cholerae, Vibrio parahaemolyticus, and Vibrio traumatica, which may pose a risk to aquatic ecosystems and human health. Presence of heavy metals in waters may exacerbate the risk of microbes to human health, as a study has found that heavy metals $\left(\mathrm{Cu}^{2+}\right.$ and $\left.\mathrm{Zn}^{2+}\right)$ significantly increased the horizontal transfer of plasmids in pathogenic bacteria, which may lead to the prevalence of drugresistant pathogenic bacteria in the water environment (Wang et al., 2021c).

Some microorganisms can become resistant to antibiotics when they are under stress. Heavy metals have been shown to increase antibiotic resistance through co-selection (Stepanauskas et al., 2006; Bednorz et al., 2013; Medardus et al., 2014). Zn, $\mathrm{Cd}$, and $\mathrm{Hg}$ have been found to be associated with methicillin resistance on Staphylococcus aureus chromosomes (Ito et al., 2001; Cavaco et al., 2010). Heavy metals can persist in the natural environment for long periods of time; therefore, their contribution to the maintenance and spread of antibiotic resistance factors may be more than we expected (Baker-Austin et al., 2006; Ji et al., 2012). MPs, which act as effective carriers of both heavy metals and biofilms, thus pose a new health threat on a global scale (Imran et al., 2019).

Furthermore, microorganisms can alter the bioavailability of heavy metals by converting heavy metals into insoluble or less bioavailable valence states through redox reactions. Bacteria such as Pseudomonas, Bacillus, Enterobacter, and Agrobacterium have been shown to have high $\mathrm{Cr}$ (VI) reduction ability (Ohtake et al., 1987). Cr (VI) reduction can be divided into enzymatic and non-enzymatic reductions. The non-enzymatic reduction is mediated by reducing substances such as glutathione and vitamin $C$, whereas the enzymatic reductions are mainly catalyzed by chromate reductases, all of which are capable of reducing highly toxic $\mathrm{Cr}$ (VI) to $\mathrm{Cr}$ (III) that does not readily enter the cell. All reported chromate reductases (e.g., ChrR, YieF, NemA, and $\mathrm{LpDH})$ use flavin as a cofactor and $\mathrm{NAD}(\mathrm{P}) \mathrm{H}$ as an electron donor, and the electron transfer mechanisms are different (Thatoi et al., 2014; Xia et al., 2021). Soluble reductase (SR) and membrane-bound reductase (MR) can also be used as $\mathrm{Cr}$ (VI) reductases, and the electron donors utilized are mainly NADH or endogenous electron reserves. From this point of view, since MPs can act as carriers of both heavy metals and microorganisms, the biofilms formed on their surfaces seem to alter the bioavailability of heavy metals more efficiently, thus exerting an unneglectable impact on the toxic effect of heavy metals.

\section{CONCLUSION AND OUTLOOK}

Evidence has shown the ubiquitous presence of MPs and heavy metals in the water environment. This paper give a perspective review on the interactions between MPs and heavy metals. The result of bibliometric analysis showed that contamination, mechanism, sediment, MPs, and pollution are the burst keywords for the latest 3 years, indicating that MP pollution is receiving widespread attention. Keyword cooccurrence mapping analysis indicated that biofilm has a high betweenness centrality. The environmental factors, including microbes, exert important influence on the interactions between MPs and heavy metals, and the combined toxic effects and the potential hazards to human health merit further concern. Our result demonstrated that microorganisms play an important role in the interaction network between heavy metals and MPs in the water environment; however, their combined effects on the aquatic ecosystem and human health are largely unknown.

Although a tremendous amount of work has been conducted in this field, substantial data gaps exist. To fill these knowledge gaps, the following issues deserve further attention:

(1) The adsorption capacity of heavy metals by MPs under multiple environmental factors is needed to evaluate the influence of environmental factors on the interactions, especially the influence of biofilm. Many of the experimental data were obtained under controlled laboratory conditions, while the adsorption of heavy metals by MPs in the natural environment is complex.

(2) The ecological and toxic effects of MPs at environmentally realistic concentrations are needed. The toxicity tests generally use new and pristine MPs with defined size and expose the organisms to high MP concentrations. Furthermore, MPs can be degraded by the biotic/abiotic factors; however, the concentration and toxicity of these smaller MPs (nanoscale and even smaller) are largely unknown, which makes risk assessment difficult.

(3) Although there are many studies on MPs and heavy metals, there is still a lack of detailed explanation on the role of microbes on their interactions. There is an urgent need for the comprehensive methods for the rapid and accurate sampling, characterization, analysis, and evaluation of the composite pollutants and their combined risks.

(4) There are still no water quality criteria for MP-related pollutants for the control of MP emissions, protection of human health, and ecosystem safety. Therefore, the cooperative efforts of scientists, policy makers, government officials, general public, and the international communities are urgently needed in the future.

\section{AUTHOR CONTRIBUTIONS}

SL: investigation, data curation, and writing-original draft. JW, YD, and HL: resources, investigation, and data curation. JL: resources, investigation, and data curation. PZ: resources, investigation, and data curation. XC: methodology and data curation. ZW: conceptualization and writing-review and editing. XL: conceptualization, supervision, and writing-review and editing. All authors contributed to the article and approved the submitted version.

\section{FUNDING}

This work was partially supported by the National Key R\&D Program of China (Grant No. 2019YFC1407800), the National Natural Science Foundation of China (NSFC No. 41807116), and the Natural Science Foundation of Tianjin City (Grant No. 19YFZCSN01130). 


\section{REFERENCES}

Abdurahman, A., Cui, K., Wu, J., Li, S., Gao, R., Dai, J., et al. (2020). Adsorption of dissolved organic matter (DOM) on polystyrene microplastics in aquatic environments: kinetic, isotherm and site energy distribution analysis. Ecotoxicol. Environ. Saf. 198:110658. doi: 10.1016/j.ecoenv.2020. 110658

Abidli, S., Akkari, N., Lahbib, Y., and Trigui El Menif, N. (2021). First evaluation of microplastics in two commercial fish species from the lagoons of Bizerte and Ghar El Melh (Northern Tunisia). Reg. Stud. Mar. Sci. 41:101581. doi: 10.1016/j.rsma.2020.101581

Akhbarizadeh, R., Moore, F., and Keshavarzi, B. (2018). Investigating a probable relationship between microplastics and potentially toxic elements in fish muscles from northeast of Persian Gulf. Environ. Pollut. 232, 154-163. doi: 10.1016/j.envpol.2017.09.028

Akhbarizadeh, R., Moore, F., Keshavarzi, B., and Moeinpour, A. (2017). Microplastics and potentially toxic elements in coastal sediments of Iran's main oil terminal (Khark IslanD). Environ. Pollut. 220, 720-731. doi: 10.1016/j. envpol.2016.10.038

Ashton, K., Holmes, L., and Turner, A. (2010). Association of metals with plastic production pellets in the marine environment. Mar. Pollut. Bull. 60, 2050-2055. doi: 10.1016/j.marpolbul.2010.07.014

Baker-Austin, C., Wright, M. S., Stepanauskas, R., and McArthur, J. V. (2006). Co-selection of antibiotic and metal resistance. Trends Microbiol. 14, 176-182. doi: 10.1016/j.tim.2006.02.006

Banaee, M., Soltanian, S., Sureda, A., Gholamhosseini, A., Haghi, B. N., Akhlaghi, M., et al. (2019). Evaluation of single and combined effects of cadmium and micro-plastic particles on biochemical and immunological parameters of common carp (Cyprinus carpio). Chemosphere 236:124335. doi: 10.1016/j. chemosphere.2019.07.066

Bandow, N., Will, V., Wachtendorf, V., and Simon, F. (2017). Contaminant release from aged microplastic. Environ. Chem. 14, 394-405. doi: 10.1071/EN17064

Bayo, J., Martinez, A., Guillen, M., Olmos, S., Roca, M., and Alcolea, A. (2017). Microbeads in commercial facial cleansers: threatening the environment. Clean (Weinh) 45:16006837. doi: 10.1002/clen.201600683

Bednorz, C., Oelgeschläger, K., Kinnemann, B., Hartmann, S., Neumann, K., Pieper, R., et al. (2013). The broader context of antibiotic resistance: zinc feed supplementation of piglets increases the proportion of multi-resistant Escherichia coli in vivo. Int. J. Med. Microbiol. 303, 396-403. doi: 10.1016/j. ijmm.2013.06.004

Benson, N. U., and Fred-Ahmadu, O. H. (2020). Occurrence and distribution of microplastics-sorbed phthalic acid esters (PAEs) in coastal psammitic sediments of tropical Atlantic Ocean. Gulf of Guinea. Sci. Total Environ. 730:139013. doi: 10.1016/j.scitotenv.2020.139013

Brennecke, D., Duarte, B., Paiva, F., Cacador, I., and Canning-Clode, J. (2016). Microplastics as vector for heavy metal contamination from the marine environment. Estuar. Coast. Shelf Sci. 178, 189-195. doi: 10.1016/j.ecss.2015. 12.003

Bryant, J. A., Clemente, T. M., Viviani, D. A., Fong, A. A., Thomas, K. A., Kemp, P., et al. (2016). Diversity and activity of communities inhabiting plastic debris in the north pacific gyre. mSystems 1, e24-e16.

Cavaco, L. M., Hasman, H., Stegger, M., Andersen, P. S., Skov, R., Fluit, A. C., et al. (2010). Cloning and occurrence of czrC, a gene conferring cadmium and zinc resistance in methicillin-resistant Staphylococcus aureus CC398 isolates. Antimicrob. Agents Chemother. 54, 3605-3608. doi: 10.1128/AAC.00058-10

Chen, S., Tan, Z., Qi, Y., and Ouyang, C. (2019). Sorption of tri-n-butyl phosphate and tris(2-chloroethyl) phosphate on polyethylene and polyvinyl chloride microplastics in seawater. Mar. Pollut. Bull. 149:110490. doi: 10.1016/ j.marpolbul.2019.110490

Chen, X., Chen, X., Zhao, Y., Zhou, H., Xiong, X., and Wu, C. (2020). Effects of microplastic biofilms on nutrient cycling in simulated freshwater systems. Sci. Total Environ. 719:137276. doi: 10.1016/j.scitotenv.2020.137276

Covernton, G. A., Davies, H. L., Cox, K. D., El-Sabaawi, R., Juanes, F., Dudas, S. E., et al. (2021). A bayesian analysis of the factors determining microplastics ingestion in fishes. J. Hazard. Mater. 413:125405. doi: 10.1016/j.jhazmat.2021. 125405

de Araújo, L. C. A., and de Oliveira, M. B. M. (2020). "Effect of heavy metals on the biofilm formed by microorganisms from impacted aquatic environments," in Bacterial Biofilms, eds S. Dincer, M. S. Özdenefe, and A. Arkut (London: IntechOpen), doi: 10.5772/intechopen.89545

Di Pippo, F., Venezia, C., Sighicelli, M., Pietrelli, L., Di Vito, S., Nuglio, S., et al. (2020). Microplastic-associated biofilms in lentic Italian ecosystems. Water Res. 187:116429. doi: 10.1016/j.watres.2020.116429

Dong, Y., Gao, M., Song, Z., and Qiu, W. (2020). As(III) adsorption onto differentsized polystyrene microplastic particles and its mechanism. Chemosphere 239:124792. doi: 10.1016/j.chemosphere.2019.124792

Duncan, E. M., Broderick, A. C., Fuller, W. J., Galloway, T. S., Godfrey, M. H., Hamann, M., et al. (2019). Microplastic ingestion ubiquitous in marine turtles. Glob. Chang. Biol. 25, 744-752. doi: 10.1111/gcb.14519

English, M. D., Robertson, G. J., Avery-Gomm, S., Pirie-Hay, D., Roul, S., Ryan, P. C., et al. (2015). Plastic and metal ingestion in three species of coastal waterfowl wintering in Atlantic Canada. Mar. Pollut. Bull. 98, 349-353. doi: 10.1016/j.marpolbul.2015.05.063

Fang, S., Yu, W., Li, C., Liu, Y., Qiu, J., and Kong, F. (2019). Adsorption behavior of three triazole fungicides on polystyrene microplastics. Sci. Total Environ. 691, 1119-1126. doi: 10.1016/j.scitotenv.2019.07.176

Feng, L., He, L., Jiang, S., Chen, J., Zhou, C., Qian, Z., et al. (2020). Investigating the composition and distribution of microplastics surface biofilms in coral areas. Chemosphere 252:126565. doi: 10.1016/j.chemosphere.2020.126565

Flemming, H., Wingender, J., and Szewzyk, U. (2016). Biofilms: an emergent form of bacterial life. Nat. Rev. Microbiol. 14, 563-575. doi: 10.1038/nrmicro.2016.94

Fu, Q., Tan, X., Ye, S., Ma, L., Gu, Y., Zhang, P., et al. (2020). Mechanism analysis of heavy metal lead captured by natural-aged microplastics. Chemosphere 270:128624. doi: 10.1016/j.chemosphere.2020.128624

Fu, Z., and Xi, S. (2019). The effects of heavy metals on human metabolism. Toxicol. Mech. Methods 30, 1-33. doi: 10.1080/15376516.2019.1701594

Godoy, V., Martínez-Férez, A., Martín-Lara, M. Á, Vellido-Pérez, J. A., Calero, M., and Blázquez, G. (2020). Microplastics as vectors of chromium and lead during dynamic simulation of the human gastrointestinal tract. Sustainability 12:4792. doi: 10.3390/su12114792

Gouin, T., Roche, N., Lohmann, R., and Hodges, G. (2011). A thermodynamic approach for assessing the environmental exposure of chemicals absorbed to microplastic. Environ. Sci. Technol. 45, 1466-1472. doi: 10.1021/es1032025

Guan, J., Qi, K., Wang, J., Wang, W., Wang, Z., Lu, N., et al. (2020). Microplastics as an emerging anthropogenic vector of trace metals in freshwater: significance of biofilms and comparison with natural substrates. Water Res. 184:116205. doi: 10.1016/j.watres.2020.116205

Guo, X., Ge, J., Yang, C., Wu, R., Dang, Z., and Liu, S. (2015). Sorption behavior of tylosin and sulfamethazine on humic acid: kinetic and thermodynamic studies. RSC Adv. 5, 58865-58872. doi: 10.1039/c5ra08684a

Guo, X., Hu, G., Fan, X., and Jia, H. (2020). Sorption properties of cadmium on microplastics: the common practice experiment and a two-dimensional correlation spectroscopic study. Ecotoxicol. Environ. Saf. 190:110118. doi: 10. 1016/j.ecoenv.2019.110118

Hirt, N., and Body-Malapel, M. (2020). Immunotoxicity and intestinal effects of nano- and microplastics: a review of the literature. Part. Fibre Toxicol. 17:57. doi: 10.1186/s12989-020-00387-7

Holmes, L. A., Turner, A., and Thompson, R. C. (2012). Adsorption of trace metals to plastic resin pellets in the marine environment. Environ. Pollut. 160, 42-48. doi: 10.1016/j.envpol.2011.08.052

Holmes, L. A., Turner, A., and Thompson, R. C. (2014). Interactions between trace metals and plastic production pellets under estuarine conditions. Mar. Chem. 167, 25-32. doi: 10.1016/j.marchem.2014.06.001

Imran, M., Das, K. R., and Naik, M. M. (2019). Co-selection of multi-antibiotic resistance in bacterial pathogens in metal and microplastic contaminated environments: an emerging health threat. Chemosphere 215, 846-857. doi: 10. 1016/j.chemosphere.2018.10.114

Ito, T., Katayama, Y., Asada, K., Mori, N., Tsutsumimoto, K., Tiensasitorn, C., et al. (2001). Structural comparison of three types of staphylococcal cassette chromosome mec integrated in the chromosome in methicillin-resistant Staphylococcus aureus. Antimicrob. Agents Chemother. 45, 1323-1336. doi: 10. 1128/AAC.45.5.1323-1336.2001

Ji, X., Shen, Q., Liu, F., Ma, J., Xu, G., Wang, Y., et al. (2012). Antibiotic resistance gene abundances associated with antibiotics and heavy metals in animal manures and agricultural soils adjacent to feedlots in Shanghai China. J. Hazard. Mater. 23, 178-185. doi: 10.1016/j.jhazmat.2012.07.040 
Jin, M., Yu, X., Yao, Z., Tao, P., Li, G., Yu, X., et al. (2020). How biofilms affect the uptake and fate of hydrophobic organic compounds (HOCs) in microplastic: insights from an in situ study of Xiangshan Bay China. Water Res. 184:116118. doi: 10.1016/j.watres.2020.116118

Jonathan, M. P., Sujitha, S. B., Rodriguez-Gonzalez, F., Campos Villegas, L. E., Hernández-Camacho, C. J., and Sarkar, S. K. (2021). Evidences of microplastics in diverse fish species off the Western Coast of Pacific Ocean, Mexico. Ocean Coast. Manag. 204:105544. doi: 10.1016/j.ocecoaman.2021.105544

Kim, D., Chae, Y., and An, Y. (2017). Mixture toxicity of nickel and microplastics with different functional groups on Daphnia magna. Environ. Sci. Technol. 51, 12852-12858. doi: 10.1021/acs.est.7b03732

Kirstein, I. V., Kirmiz, S., Wichels, A., Garin-Fernandez, A., Erler, R., and Martin Löder, G. G. (2016). Dangerous hitchhikers? evidence for potentially pathogenic Vibrio spp. on microplastic particles. Mar. Environ. Res. 120, 1-8. doi: 10.1016/ j.marenvres.2016.07.004

Kleinteich, J., Seidensticker, S., Marggrander, N., and Zarfl, C. (2018). Microplastics reduce short-term effects of environmental contaminants. part ii: polyethylene particles decrease the effect of polycyclic aromatic hydrocarbons on microorganisms. Int. J. Environ. Res. Public Health 15:287. doi: 10.3390/ ijerph15020287

Lang, M., Yu, X., Liu, J., Xia, T., Wang, T., Jia, H., et al. (2020). Fenton aging signi ficantly affects the heavy metal adsorption capacity of polystyrene microplastics. Sci. Total Environ. 722:137762. doi: 10.1016/j.scitotenv.2020.137762

Langmuir, I. (1918). The adsorption of gases on plane surfaces of glass,mica and platinum. J. Am. Chem. Soc. 40, 1361-1403. doi: 10.1021/ja02242a004

Laverty, A. L., Primpke, S., Lorenz, C., Gerdts, G., and Dobbs, F. C. (2020). Bacterial biofilms colonizing plastics in estuarine waters, with an emphasis on Vibrio spp. and their antibacterial resistance. PLoS One 15:e237704. doi: 10.1371/journal. pone.0237704

Li, J., Huang, W., Jiang, R., Han, X., Zhang, D., and Zhang, C. (2020). Are bacterial communities associated with microplastics influenced by marine habitats? Sci. Total Environ. 733:139400. doi: 10.1016/j.scitotenv.2020.139400

Liao, Y., and Yang, J. (2020). Microplastic serves as a potential vector for Cr in an in-vitro human digestive model. Sci. Total Environ. 703:134805. doi: 10.1016/j. scitotenv.2019.134805

Lin, Z., Hu, Y., Yuan, Y., Hu, B., and Wang, B. (2021). Comparative analysis of kinetics and mechanisms for $\mathrm{Pb}$ (II) sorption onto three kinds of microplastics. Ecotoxicol. Environ. Saf. 208:111451. doi: 10.1016/j.ecoenv.2020.111451

Liu, G., Zhu, Z., Yang, Y., Sun, Y., Yu, F., and Ma, J. (2019). Sorption behavior and mechanism of hydrophilic organic chemicals to virgin and aged microplastics in freshwater and seawater. Environ. Pollut. 246, 26-33. doi: 10.1016/j.envpol. 2018.11.100

Llorca, M., Ábalos, M., Vega-Herrera, A., Adrados, M. A., Abad, E., and Farré, M. (2020). Adsorption and desorption behaviour of polychlorinated biphenyls onto microplastics' surfaces in water/sediment systems. Toxics 8:59. doi: 10 . 3390/toxics 8030059

Loncarski, M., Tubic, A., Kragulj-Isakovski, M., Jovic, B., Apostolovic, T., Nikic, J., et al. (2020). Modelling of the adsorption of chlorinated phenols on polyethylene and polyethylene terephthalate microplastic. J. Serbian Chem. Soc. 85, 697-709. doi: 10.2298/JSC190712124L

Mao, R., Lang, M., Yu, X., Wu, R., Yang, X., and Guo, X. (2020). Aging mechanism of microplastics with UV irradiation and its effects on the adsorption of heavy metals. J. Hazard. Mater. 393:122515. doi: 10.1016/j.jhazmat.2020.122515

Martinez-Tavera, E., Duarte-Moro, A. M., Sujitha, S. B., Rodriguez-Espinosa, P. F., Rosano-Ortega, G., and Expósito, N. (2021). Microplastics and metal burdens in freshwater Tilapia (Oreochromis niloticus) of a metropolitan reservoir in Central Mexico: potential threats for human health. Chemosphere 266:128968. doi: 10.1016/j.chemosphere.2020.128968

Massos, A., and Turner, A. (2017). Cadmium, lead and bromine in beached microplastics. Environ. Pollut. 227, 139-145. doi: 10.1016/j.envpol.2017.04.034

Medardus, J. J., Molla, B. Z., Nicol, M., Morrow, W. M., Rajala-Schultz, P. J., Kazwala, R., et al. (2014). In-feed use of heavy metal micronutrients in U.S. swine production systems and its role in persistence of multidrug-resistant salmonellae. Appl. Environ. Microbiol. 80, 2317-2325. doi: 10.1128/AEM. 04283-13

Milatou, N., Dassenakis, M., and Megalofonou, P. (2020). Mercury concentrations in reared Atlantic bluefin tuna and risk assessment for the consumers: to eat or not to eat? Food Chem. 331:127267. doi: 10.1016/j.foodchem.2020.127267
Mincer, T. J., Zettler, E. R., and Amaral-Zettler, L. A. (2016). Biofilms on plastic debris and their influence on marine nutrient cycling, productivity, and hazardous chemical mobility. Handb. Environ. Chem. 78, 221-233. doi: 10. 1007/698_2016_12

Murphy, F., and Quinn, B. (2018). The effects of microplastic on freshwater Hydra attenuata feeding, morphology \& reproduction. Environ. Pollut. 234, 487-494. doi: 10.1016/j.envpol.2017.11.029

Nethaji, S., Sivasamy, A., and Mandal, A. B. (2013). Adsorption isotherms, kinetics and mechanism for the adsorption of cationic and anionic dyes onto carbonaceous particles prepared from Juglans regia shell biomass. Int. J. Environ. Sci. Technol. 10, 231-242. doi: 10.1007/s13762-0120112-0

Ohtake, H., Cervantes, C., and Silver, S. (1987). Decreased chromate uptake in Pseudomonas fluorescens carrying a chromate resistance plasmid. J. Bacteriol. 169, 3853-3856. doi: 10.1128/jb.169.8.3853-3856.1987

Oliviero, M., Tato, T., Schiavo, S., Fernandez, V., Manzo, S., and Beiras, R. (2019). Leachates of micronized plastic toys provoke embryotoxic effects upon sea urchin Paracentrotus lividus. Environ. Pollut. 247, 706-715. doi: 10.1016/j. envpol.2019.01.098

Oz, N., Kadizade, G., and Yurtsever, M. (2019). Investigation of heavy metal adsorption on microplastics. Appl. Ecol. Environ. Res. 17, 7301-7310. doi: 10. 15666/aeer/1704_73017310

Prunier, J., Maurice, L., Perez, E., Gigault, J., Pierson-Wickmann, A., Davranche, M., et al. (2019). Trace metals in polyethylene debris from the North Atlantic subtropical gyre. Environ. Pollut. 245, 371-379. doi: 10.1016/j.envpol.2018. 10.043

Purwiyanto, A. I. S., Suteja, Y., Trisno, Ningrum, P. S., Putri, W. A. E., Rozirwan, et al. (2020). Concentration and adsorption of $\mathrm{Pb}$ and $\mathrm{Cu}$ in microplastics: case study in aquatic environment. Mar. Pollut. bull. 158:111380. doi: 10.1016/ j.marpolbul.2020.111380

Qi, K., Lu, N., Zhang, S., Wang, W., Wang, Z., and Guan, J. (2021). Uptake of Pb(II) onto microplastic-associated biofilms in freshwater: adsorption and combined toxicity in comparison to natural solid substrates. J. Hazard. Mater. 411:125115. doi: 10.1016/j.jhazmat.2021.125115

Rahman, A., Sarkar, A., Yadav, O. P., Achari, G., and Slobodnik, J. (2021). Potential human health risks due to environmental exposure to nano- and microplastics and knowledge gaps: a scoping review. Sci. Total Environ. 757:143872. doi: 10.1016/j.scitotenv.2020.143872

Richard, H., Carpenter, E. J., Komada, T., Palmer, P. T., and Rochman, C. M. (2019). Biofilm facilitates metal accumulation onto microplastics in estuarine waters. Sci. Total Environ. 683, 600-608. doi: 10.1016/j.scitotenv.2019.04.331

Robin, R. S., Karthik, R., Purvaja, R., Ganguly, D., Anandavelu, I., Mugilarasan, M., et al. (2020). Holistic assessment of microplastics in various coastal environmental matrices, southwest coast of India. Sci. Total Environ. 703:134947. doi: 10.1016/j.scitotenv.2019.134947

Rogers, K. L., Carreres Calabuig, J. A., Gorokhova, E., and Posth, N. R. (2020). Micro-by-micro interactions: how microorganisms influence the fate of marine microplastics. Limnol. Oceanogr. Lett. 5, 18-36. doi: 10.1002/lol2. 10136

Rummel, C. D., Jahnke, A., Gorokhova, E., Kühnel, D., and Schmitt-Jansen, M. (2017). Impacts of biofilm formation on the fate and potential effects of microplastic in the aquatic environment. Environ. Sci. Technol. Lett. 4, 258-267. doi: 10.1021/acs.estlett.7b00164

Sapea Working Group on Microplastics. (2019). A Scientific Perspective on Microplastics in Nature and Society. https://www.researchgate.net/project/AScientific-Perspective-on-Microplastics-in-Nature-and-Society (accessed October 15, 2020)

Sarkar, D. J., Das Sarkar, S., Das, B. K., Sahoo, B. K., Das, A., Nag, S. K., et al. (2021). Occurrence, fate and removal of microplastics as heavy metal vector in natural wastewater treatment wetland system. Water Res. 192:116853. doi: 10.1016/j.watres.2021.116853

Schwabl, P., Köppel, S., Königshofer, P., Bucsics, T., Trauner, M., Reiberger, T., et al. (2019). Detection of various microplastics in human stool. Ann. Intern. Med. 171:453. doi: 10.7326/m19-0618

Shan, J., Wang, J., Zhan, J., Liu, L., Wu, F., and Wang, X. (2020). Sorption behaviors of crude oil on polyethylene microplastics in seawater and digestive tract under simulated real-world conditions. Chemosphere 257:127225. doi: 10.1016/j.chemosphere.2020.127225 
Sheng, G., Yu, H., and Li, X. (2010). Extracellular polymeric substances (EPS) of microbial aggregates in biological wastewater treatment systems: a review. Biotechnol. Adv. 28, 882-894. doi: 10.1016/j.biotechadv.2010.08.001

Smith, M., Love, D. C., Rochman, C. M., and Neff, R. A. (2018). Microplastics in seafood and the implications for human health. Curr. Environ. Health Rep. 5, 375-386. doi: 10.1007/s40572-018-0206-Z

So, W. K., Chan, K., and Not, C. (2018). Abundance of plastic microbeads in Hong Kong coastal water. Mar. Pollut. Bull. 133, 500-505. doi: 10.1016/j. marpolbul.2018.05.066

Steer, M., Cole, M., Thompson, R. C., and Lindeque, P. K. (2017). Microplastic ingestion in fish larvae in the western english channel. Environ. Pollut. 226, 250-259. doi: 10.1016/j.envpol.2017.03.062

Stepanauskas, R., Glenn, T. C., Jagoe, C. H., Tuckfield, R. C., Lindell, A. H., King, C. J., et al. (2006). Coselection for microbial resistance to metals and antibiotics in freshwater microcosms. Environ. Microbiol. 8, 1510-1514. doi: 10.1111/j.1462-2920.2006.01091.x

Sun, J., Xia, S., Ning, Y., Pan, X., Qu, J., and Xu, Y. (2019). Effects of microplastics and attached heavy metals on growth, immunity, and heavy metal accumulation in the yellow seahorse, Hippocampus kuda Bleeker. Mar. Pollut. Bull. 149:110510. doi: 10.1016/j.marpolbul.2019.110510

Sun, X., Chen, B., Xia, B., Li, Q., Zhu, L., Zhao, X., et al. (2020). Impact of mariculture-derived microplastics on bacterial biofilm formation and their potential threat to mariculture: a case in situ study on the Sungo Bay China. Environ. Pollut. 262:114336. doi: 10.1016/j.envpol.2020.114336

Svecevièius, G., Sauliutë, G., Idzelis, R. L., and Grigelevièiûtë, J. (2014). Accumulation of heavy metals in different body tissues of Atlantic salmon, Salmo salar $\mathrm{L}$., exposed to a model mixture $(\mathrm{Cu}, \mathrm{Zn}, \mathrm{Ni}, \mathrm{Cr}, \mathrm{Pb}, \mathrm{Cd})$ and singly to nickel, chromium, and lead. Bull. Environ. Contam. Toxicol. 92, 440-445. doi: 10.1007/s00128-014-1237-2

Ta, A. T., and Babel, S. (2020). Microplastics pollution with heavy metals in the aquaculture zone of the Chao Phraya River Estuary Thailand. Mar. Pollut. Bull. 161:111747. doi: 10.1016/j.marpolbul.2020.111747

Taha, A. A., Shreadah, M. A., Ahmed, A. M., and Heiba, H. F. (2016). Multicomponent adsorption of $\mathrm{Pb}(\mathrm{II}), \mathrm{Cd}(\mathrm{II})$, and $\mathrm{Ni}(\mathrm{II})$ onto Egyptian Na-activated bentonite; equilibrium, kinetics, thermodynamics, and application for seawater desalination. J. Environ. Chem. Eng. 4, 1166-1180. doi: 10.1016/j.jece.2016. 01.025

Tang, S., Lin, L., Wang, X., Feng, A., and Yu, A. (2020). Pb(II) uptake onto nylon microplastics: Interaction mechanism and adsorption performance. J. Hazard. Mater. 386:121960. doi: 10.1016/j.jhazmat.2019.121960

Tayebi, L., and Sobhanardakani, S. (2019). Analysis of heavy metal contents and non-carcinogenic health risk assessment through consumption of Tilapia Fish (Oreochromis niloticus). Biol. Trace Elem. Res. 6, 59-67. doi: 10.22059/poll.2019. 284500.639

Tchounwou, P. B., Yedjou, C. G., Patlolla, A. K., and Sutton, D. J. (2012). Heavy metals toxicity and the environment. Exp. Suppl. 101, 133-164. doi: 10.1007/ 978-3-7643-8340-4_6

Thatoi, H., Das, S., Mishra, J., Rath, B. P., and Das, N. (2014). Bacterial chromate reductase, a potential enzyme for bioremediation of hexavalent chromium: a review. J. Environ. Manag. 146, 383-399. doi: 10.1016/j.jenvman.2014.07.014

Thompson, R. C., Olsen, Y., Mitchell, R. P., Davis, A., Rowland, S. J., John, A. W. G., et al. (2004). Lost at sea: where is all the plastic? Science 304:838. doi: $10.1126 /$ science. 1094559

Torres, F. G., Dioses-Salinas, D. C., Pizarro-Ortega, C. I., and De-la-Torre, G. E. (2021). Sorption of chemical contaminants on degradable and nondegradable microplastics: recent progress and research trends. Sci. Total Environ. 757:143875. doi: 10.1016/j.scitotenv.2020.143875

Tu, C., Chen, T., Zhou, Q., Liu, Y., Wei, J., Waniek, J. J., et al. (2020). Biofilm formation and its influences on the properties of microplastics as affected by exposure time and depth in the seawater. Sci. Total Environ. 734:139237. doi: 10.1016/j.scitotenv.2020.139237

Turner, A., Wallerstein, C., and Arnold, R. (2019). Identification, origin and characteristics of bio-bead microplastics from beaches in western Europe. Sci. Total Environ. 664, 938-947. doi: 10.1016/j.scitotenv.2019.01.281

van Franeker, J. A., Blaize, C., Danielsen, J., Fairclough, K., Gollan, J., Guse, N., et al. (2011). Monitoring plastic ingestion by the northern fulmar Fulmarus glacialis in the North Sea. Environ. Pollut. 159, 2609-2615. doi: 10.1016/j.envpol.2011. 06.008
Vedolin, M. C., Teophilo, C. Y. S., Turra, A., and Figueira, R. C. L. (2018). Spatial variability in the concentrations of metals in beached microplastics. Mar. Pollut. Bull. 129, 487-493. doi: 10.1016/j.marpolbul.2017.10.019

Wang, J., Li, J., Liu, S., Li, H., Chen, X., Peng, C., et al. (2021a). Distinct microplastic distributions in soils of different land-use types: a case study of Chinese farmlands. Environ. Pollut. 269:116199. doi: 10.1016/j.envpol.2020.116199

Wang, J., Liu, X., Li, Y., Powell, T., Wang, X., Wang, G., et al. (2019a). Microplastics as contaminants in the soil environment: a mini-review. Sci. Total Environ. 691, 848-857. doi: 10.1016/j.scitotenv.2019.07.209

Wang, J., Lu, L., Wang, M., Jiang, T., Liu, X., and Ru, S. (2019b). Typhoons increase the abundance of microplastics in the marine environment and cultured organisms: a case study in Sanggou Bay China. Sci. Total Environ. 667, 1-8. doi: 10.1016/j.scitotenv.2019.02.367

Wang, J., Peng, C., Li, H., Zhang, P., and Liu, X. (2021b). The impact of microplastic-microbe interactions on animal health and biogeochemical cycles: a mini-review. Sci. Total Environ. 773:145697. doi: 10.1016/j.scitotenv.2021. 145697

Wang, J., Qin, X., Guo, J., Jia, W., Wang, Q., Zhang, M., et al. (2020). Evidence of selective enrichment of bacterial assemblages and antibiotic resistant genes by microplastics in urban rivers. Water Res. 183:116113. doi: 10.1016/j.watres. 2020.116113

Wang, L., Luo, Z., Zhen, Z., Yan, Y., Yan, C., Ma, X., et al. (2020). Bacterial community colonization on tire microplastics in typical urban water environments and associated impacting factors. Environ. Pollut. 265:114922. doi: 10.1016/j.envpol.2020.114922

Wang, Q., Xu, Y., Liu, L., Li, L., Lin, H., Wu, X., et al. (2021c). The prevalence of ampicillin-resistant opportunistic pathogenic bacteria undergoing selective stress of heavy metal pollutants in the Xiangjiang River, China. Environ. Pollut. 268:115362. doi: 10.1016/j.envpol.2020.115362

Wang, Q., Zhang, Y., Wangjin, X., Wang, Y., Meng, G., and Chen, Y. (2020). The adsorption behavior of metals in aqueous solution by microplastics effected by UV radiation. J. Environ. Sci. 87, 272-280. doi: 10.1016/j.jes.2019.07.006

Wang, T., Yu, C., Chu, Q., Wang, F., Lan, T., and Wang, J. (2020). Adsorption behavior and mechanism of five pesticides on microplastics from agricultural polyethylene films. Chemosphere 244:125491. doi: 10.1016/j.chemosphere.2019. 125491

Wen, B., Jin, S., Chen, Z., Gao, J., Liu, Y., Liu, J., et al. (2018a). Single and combined effects of microplastics and cadmium on the cadmium accumulation, antioxidant defence and innate immunity of the discus fish (Symphysodon aequifasciatus). Environ. Pollut. 243, 462-471. doi: 10.1016/j.envpol.2018.09. 029

Wen, B., Zhang, N., Jin, S., Chen, Z., Gao, J., Liu, Y., et al. (2018b). Microplastics have a more profound impact than elevated temperatures on the predatory performance, digestion and energy metabolism of an Amazonian cichlid. Aquat. Toxicol. 195, 67-76. doi: 10.1016/j.aquatox.2017.12.010

World Health Organization (Who). (2019). Microplastics in Drinking-Water. https://www.aquasana.com/info/news/dangerous-plastic-fibers-in-ourdrinking-water-microplastics (accessed October 15, 2020)

Xia, X., Wu, S., Zhou, Z., and Wang, G. (2021). Microbial Cd(II) and Cr(VI) resistance mechanisms and application in bioremediation. J. Hazard. Mater. 401:123685. doi: 10.1016/j.jhazmat.2020.123685

Xue, N., Wang, L., Li, W., Wang, S., Pan, X., and Zhang, D. (2020). Increased inheritance of structure and function of bacterial communities and pathogen propagation in plastisphere along a river with increasing antibiotics pollution gradient. Environ. Pollut. 265:114641. doi: 10.1016/j.envpol.2020. 114641

Yan, W., Hamid, N., Deng, S., Jia, P., and Pei, D. (2020). Individual and combined toxicogenetic effects of microplastics and heavy metals $(\mathrm{Cd}, \mathrm{Pb}$, and $\mathrm{Zn})$ perturb gut microbiota homeostasis and gonadal development in marine medaka (Oryzias melastigma). J. Hazard. Mater. 397:122795. doi: 10.1016/j.jhazmat. 2020.122795

Yang, Y., Liu, W., Zhang, Z., Grossart, H., and Gadd, G. M. (2020). Microplastics provide new microbial niches in aquatic environments. Appl. Microbiol. Biotechnol. 104, 6501-6511. doi: 10.1007/s00253-020-10704-x

Yin, K., Wang, Y., Zhao, H., Wang, D., Guo, M., Mu, M., et al. (2021). A comparative review of microplastics and nanoplastics: toxicity hazards on digestive, reproductive and nervous system. Sci. Total Environ. 774:145758. doi: $10.1016 /$ j.scitotenv.2021.145758 
Zahra, N. (2017). Perilous effects of heavy metals contamination on human health. Pak. J. Anal. Environ. Chem. 18, 1-17. doi: 10.21743/pjaec/2017.06.01

Zhang, B., Chen, L., Chao, J., Yang, X., and Wang, Q. (2020). Research progress of microplastics in freshwater sediments in China. Environ. Sci. Pollut. Res. 27, 31046-31060. doi: 10.1007/s11356-020-09473-x

Zhang, S., Han, B., Sun, Y., and Wang, F. (2020). Microplastics influence the adsorption and desorption characteristics of $\mathrm{Cd}$ in an agricultural soil. J. Hazard. Mater. 388:121775. doi: 10.1016/j.jhazmat.2019.121775

Zhang, W., Zhang, L., Hua, T., Li, Y., Zhou, X., Wang, W., et al. (2020). The mechanism for adsorption of $\mathrm{Cr}(\mathrm{VI})$ ions by $\mathrm{PE}$ microplastics in ternary system of natural water environment. Environ. Pollut. 257:113440. doi: 10.1016/ j.envpol.2019.113440

Zhang, X., Zheng, M., Wang, L., Lou, Y., Shi, L., and Jiang, S. (2018). Sorption of three synthetic musks by microplastics. Mar. Pollut. Bull. 126, 606-609. doi: 10.1016/j.marpolbul.2017.09.025

Zhu, X., Qiang, L., Shi, H., and Cheng, J. (2020). Bioaccumulation of microplastics and its in vivo interactions with trace metals in edible oysters. Mar. Pollut. Bull. 154:111079. doi: 10.1016/j.marpolbul.2020.111079

Zitouni, N., Bousserrhine, N., Belbekhouche, S., Missawi, O., Alphonse, V., Boughatass, I., et al. (2020). First report on the presence of small microplastics $(=3 \mu \mathrm{m})$ in tissue of the commercial fish Serranus scriba (Linnaeus. 1758) from Tunisian coasts and associated cellular alterations. Environ. Pollut. 263:114576. doi: 10.1016/j.envpol.2020. 114576

Zon, N. F., Iskendar, A., Azman, S., Sarijan, S., and Ismail, R. (2018). Sorptive behaviour of chromium on polyethylene microbeads in artificial seawater. MATEC Web Conf. 250:6001. doi: 10.1051/matecconf/2018250 06001

Conflict of Interest: The authors declare that the research was conducted in the absence of any commercial or financial relationships that could be construed as a potential conflict of interest.

Copyright (® $2021 \mathrm{Liu}$, Shi, Wang, Dai, Li, Li, Liu, Chen, Wang and Zhang. This is an open-access article distributed under the terms of the Creative Commons Attribution License (CC BY). The use, distribution or reproduction in other forums is permitted, provided the original author(s) and the copyright owner(s) are credited and that the original publication in this journal is cited, in accordance with accepted academic practice. No use, distribution or reproduction is permitted which does not comply with these terms. 